\title{
UJI AKTIVITAS ANTIBAKTERI EKSTRAK ETANOL DAUN MELINJO (Gnetum gnemon L.) TERHADAP PERTUMBUHAN BAKTERI Staphylococcus aureus dan Streptococcus mutans
}

\author{
Firdaus Fahdi, Linda Margata, Sindy Ariska, \\ Evi Depiana Gultom, Linta Meliala \\ Fakultas Farmasi, Institut Kesehatan Deli Husada Deli Tua \\ e-mail: daus2966@gmail.com
}

\begin{abstract}
Nowadays, the use of traditional medicine is becoming more popular in society. One of those traditional medicine is Gnetum gnemon L. Gnetum gnemon can be used as a medicine that has the function of antibacterial. Chemical content in it that is antibacterial are flavonoids and tannins. The aim of this study is to find out the antibacterial effects from ethanol extract from melinjo leaves. Melinjo leaves extract concentration is $300 \mathrm{mg} / \mathrm{ml}, 400 \mathrm{mg} / \mathrm{ml}$, and $500 \mathrm{mg} / \mathrm{ml}$. The test of antibacterial activity for the growth Staphylococcus aureus and Streptococcus mutans is done by using the disc diffusion method. The results showed that melinjo leaves contains an alkaloid, flavonoid, tannin, steroid and saponin compounds. The results of the simplicia powder characteristics obtained a total ash content of $7.495 \%$, ash content insoluble in acid $0.785 \%$, ethanol-soluble extract $4.324 \%$, water-soluble extract $17.690 \%$. The results of the antibacterial activity test of the ethanol extract of melinjo leaves obtained can inhibit the growth of Staphylococcus aureus and Streptococcus mutans namely at a concentration of $300 \mathrm{mg} / \mathrm{ml}, 400 \mathrm{mg} / \mathrm{ml}$, and $500 \mathrm{mg} / \mathrm{ml}$ into the medium inhibition zone category. Ethanol extract of melinjo leaves has antibacterial activity against the growth of Staphylococcus aureus and Streptococcus mutans with an average diameter of inhibition zone of $9.7 \mathrm{~mm}$ (medium category) against Staphylococcus aureus and $6.7 \mathrm{~mm}$ (medium category) against bacteria Streptococcus mutans.
\end{abstract}

Keywords: Gnetum gnemon L., Antibacterial Activity Test, Inhibitory Zone

\section{PENDAHULUAN}

Daerah tropis seperti Indonesia khususnya terdapat banyak tanaman yang dapat dimanfaatan sebagai obat-obatan. Salah satunya adalah melinjo (Gnetum gnemon L.), tanaman ini adalah tanaman tropis dan banyak ditemukan di Indonesia. Masyarakat pada umumnya menggunakan melinjo sebagai bahan dasar untuk membuat emping. Melinjo juga lazim dimanfaatkan sebagai obat beberapa jenis penyakit seperti anemia/kurang darah, penyakit mata, kesulitan buang air kecil, dan kwashiorkor (Hariana, 2008). Pada selembar daun melinjo terdapat 
kandungan senyawa aktif yang memiliki banyak manfaat seperti flavonoid, alkaloid, tannin dan steroid (Kining, 2015). Dari senyawa-senyawa aktif tersebut, flavonoid dan tanin tercatat mempunyai kemampuan efek antibakteri (Noor, 2014).

Melinjo umum digunakan
sebagai obat tradisional.

Pengobatan tradisional yang berasal dari tumbuhan dapat menyehatkan dan sedikit/bahkan tidak menimbulkan efek samping apabila dibanding dengan obat-obatan produksi pabrik atau dari bahan kimia. Penelitian tanaman herbal yang memiliki aktivitas antibakteri sudah banyak dilakukan (Stevani, 2016).

Infeksi akibat bakteri merupakan hal yang biasa terjadi salah satu bakteri yang banyak menginfeksi adalah Staphylococcus aureus, namun derajat keparahan yang ditimbulkan pada tiap individu berbeda-beda, contohnya keracunan makanan yang tercemar bakteri atau pada hejala ringan seperti infeksi kulit dan pada kondisi berat dapat mengancam keselamatan.

Bakteri

Staphylococcus merupakan flora normal pada manusia, sehingga bakteri ini dapat ditemukan pada saluran pernafasan, saluran pencernaan, dan kulit (Jawetz, 2008).

Pada penelitian-penelitian sebelumnya belum ditemukan besaran luas zona hambat dan pada besaran konsentrasi berapa ekstrak etanol daun melinjo dapat memberikan efek aktivitas antibakteri terhadap pertumbuhan bakteri Streptococcus mutans (Natalia, dkk, 2016). Penelitian lain yang dilakukan oleh Rafika (2017) juga belum mengetahui uji aktivitas antibakteri daun melinjo terhadap pertumbuhan bakteri Staphylococcus aureus. Karena itu pada penelitian ini, peneliti ingin melihat Uji Aktivitas Antibakteri Ekstrak Etanol Daun Melinjo (Gnetum Gnemon L.) Terhadap Pertumbuhan Bakteri Staphylococcus Aureus Dan Streptococcus Mutans.

\section{METODE}

Alat yang di gunakan dalam penelitian ini yaitubatang pengaduk, aluminium foil, bunsen, autoklaf, beaker glass, blender, cawan petri, cawan porselin, inkubator, gunting, hot plate, kawat ose, kertas difusi cakram, kertas saring, jangka sorong, laminal air flow, labu ukur, erlenmeyer, mikropipet, oven, pipet tetes, spatula, penangas air, rotary evaporator, tabung reaksi, rak tabung reaksi, dan timbangan analitik.

Penelitian ini menggunakan bahan-bahan seperti amoniak, asam sulfat, asam asetat anhidrat, asam klorida, aquadest, biakan murni bakteri Streptococcus mutans dan Staphylococcus aureus yang di peroleh dari laboratorium Universitas Sumatera Utara, bubuk magnesium, daun melinjo mentah (yang belum di keringkan) \pm sebanyak $5 \mathrm{~kg}$ yang di peroleh dari daerah Deli Tua Timur, etanol 96 
$\%, \mathrm{FeCl} 3$, kloroform, kontrol negatif akuades, kontrol positif Amoxicillin tablet $500 \mathrm{mg}, \mathrm{BaCl} 2-2 \mathrm{H} 2 \mathrm{O}$ $1,175 \%$, larutan DMSO, Nutrient Agar (NA), pereaksi Dragendorff, pereaksi Lieberman-Bouchardat, pereaksi mayer.

Bakteri uji yang digunkan adalah kultur murni Streptococcus mutans dan Staphylococcus aureus. Kedua bakteri ini didapatkan dari koleksi Laboratorium Mikrobiologi Farmasi Fakultas Farmasi Institut Kesehatan Deli Husada Deli Tua.

Simplisia daun melinjo
diekstraksi dengan metode
maserasi, proses pengerjaan metode ini yaitu dengan merendam simplisia daun melinjo dalam pelarut etanol $96 \%$ selama $5-7$ hari dan selama perendaman dilakukan pengadukan 2 sampai 3 kali, selanjutnya disaring dengan kertas saring. Maserat seluruhnya dikumpulkan kemudian diproses menggunakan rotary evaporator pada suhu $40^{\circ} \mathrm{C}$, selanjutnya dengan menggunakan cawan penguap filtrat yang tersisa diuapkan diatas waterbath sampai didapatkan ekstrak dengan kekentalan yang diinginkan.

Penentuan komponen bioaktif ekstrak etanol daun melinjo dilakukan dengan uji fitokimia. Uji fitokimia ini meliputi uji flavonoid, steroid, alkaloid, tannin dan saponin. Proses standarisasi ekstrak dilakukan dengan parameter spesifik dan non-spesisfik. Yang termasuk kedalam parameter spesifik adalah uji senyawa terlarut dalam pelarut air dan etanol dan uji organopletis. Sedangkan parameter non-spesifik meliputi, kadar abu total, kadar sari larut dalam etanol, kadar air, kadar sari larut dalam air, dan kadar abu tidak larut dalam asam.

$\mathrm{Uji}$ aktivitas antibakteri dilakukan menggunakan metode difusi cakram. Tahap-tahap persiapan meliputi meremajakan bakteri, membuat suspensi bakteri, membuat cakram kertas, mempersiapkan kontrol positif, mempersiapkan kontrol negatif, dan proses pembuatan konsentrasi ekstrak yaitu konsentrasi 300 $\mathrm{mg} / \mathrm{ml}, 400 \mathrm{mg} / \mathrm{ml}$, dan 500 $\mathrm{mg} / \mathrm{ml}$. Suspensi bakteri uji dimasukkan pada media dalam petri kemudian digoreskan dengan kawat ose steril diatas media uji. Prosedur ini diulangin sebanyak tiga kali. Kertas cakram dengan diameter $6 \mathrm{~mm}$. Kontrol positif yaitu Amoxicillin 500 mg, kontrol negatif DMSO sebanyak $15 \mathrm{ml}$, ekstrak etanol daun melinjo (Gnetum gnemon L.) dengan konsentrasi $300 \mathrm{mg} / \mathrm{ml}, 400$ $\mathrm{mg} / \mathrm{ml}$, dan $500 \mathrm{mg} / \mathrm{ml}$. Selanjutnya, kertas cakram ditempatkan pada bagian atas permukaan media. Kemudian media tersebut diinkubasi dengan temperatur $37^{\circ} \mathrm{C}$ selama 24 jam, selanjutnya proses pengukuran diameter zona hambat menggunakan jangka sorong, yang dinyatakan dalam satuan millimeter. Analisis data yan digunakan dengan SPSS dan uji One Way Anova. 


\section{HASIL}

Setelah dilakukan skrining fitokimia simplisia daun melinjo, didapatkan hasil bahwa terdapat kandungan alkaloid, flavonoid, steroid, saponin, dan tannin dalam ekstrak daun melinjo (Gnetum gnemon L.).

Tabel 1. Hasil Skrining fitokimia simplisia daun melinjo.

\begin{tabular}{|l|l|}
\hline $\begin{array}{l}\text { Golongan } \\
\text { Senyawa }\end{array}$ & Hasil \\
\hline Alkaloid & $(+)$ Alkaloid \\
\hline Flavonoid & $(+)$ Flavonoid \\
\hline Saponin & $(+)$ Saponin \\
\hline Steroid & $(+)$ Steroid \\
\hline Tannin & $(+)$ Tannin \\
\hline
\end{tabular}

Hasil uji karakterisasi simplisia daun melinjo (Gnetum gnemon L.) bertujuan untuk mengetahui kadar air, kadar abu total, kadar sari larut dalam etanol, kadar abu tidak larut dalam asam, dan kadar sari larut dalam air yang terdapat dalam daun melinjo. Pengukuran ini dlakukan sesuai standar SNI (Standar Nasional Indonesia), sebagai acuan karakterisasi. SNI merupakan penentu syarat mutu perdagangan di Indonesia.
Tabel 2. Hasil Karakterisasi simplisia daun melinjo (Gnetum gnemon L.)

\begin{tabular}{|l|l|l|}
\hline $\begin{array}{l}\text { Paramete } \\
r\end{array}$ & $\begin{array}{l}\text { Persyara } \\
\text { tan MMI }\end{array}$ & $\begin{array}{l}\text { Simplisia } \\
\text { Daun } \\
\text { Melinjo }\end{array}$ \\
\hline $\begin{array}{l}\text { Kadar air } \\
\%\end{array}$ & $<10 \%$ & $4,5 \%$ \\
\hline $\begin{array}{l}\text { Kadar sari } \\
\text { larut } \\
\text { dalam air } \\
\%\end{array}$ & $>16 \%$ & $\begin{array}{l}17, \\
690 \%\end{array}$ \\
\hline $\begin{array}{l}\text { Kadar sari } \\
\text { larut } \\
\text { dalam } \\
\text { etanol \% }\end{array}$ & $>3,30 \%$ & $4,324 \%$ \\
\hline $\begin{array}{l}\text { Kadar abu } \\
\text { total \% }\end{array}$ & $<8,2 \%$ & $7,495 \%$ \\
\hline
\end{tabular}

Penelitian ini telah selesai dilakukan di Laboratorium Mikrobiologi Fakultas Farmasi, Institut Kesehatan Deli Husada Deli Tua. Dalam penelitian ini terdapat 3 kelompok yaitu ekstrak daun melinjo (Gnetum gnemon L.) yang merupakan kelompok perlakuan, amoxicillin sebagai kontrol positif dan DMSO sebagai kontrol negatif. Ketiga kelompok ini menggunakan kertas cakram berdiameter $6 \mathrm{~mm}$. Konsentrasi ekstrak daun melinjo (Gnetum gnemon L.) adalah 300 $\mathrm{mg} / \mathrm{ml}$, $400 \mathrm{mg} / \mathrm{ml}$, dan 500 $\mathrm{mg} / \mathrm{ml}$. Besaran diameter zona hambat dari ketiga kelompok yaitu ekstrak daun melinjo (Gnetum gnemon L.), amoxicillin dan DMSO terhadap pertumbuhan bakteri Streptococcus mutans dan 
Staphylococcus aureus dapat dilihat pada Tabel 3.

Tabel 3. Diameter Luas Zona Hambat Ekstrak Daun Melinjo (Gnetum gnemon L.), Amoxicillin (kontrol +), DMSO (kontrol -) Pada Bakteri S. aureus dan S. mutans.

\begin{tabular}{|l|l|l|}
\hline \multirow{2}{*}{ Perlakuan } & $\begin{array}{l}\text { Rata-Rata } \\
\text { Zona } \\
(\mathrm{mm})\end{array}$ & \multicolumn{1}{|l|}{$\begin{array}{r}\text { Luas } \\
\text { Hambat }\end{array}$} \\
\cline { 2 - 3 } & S.aureus & $\begin{array}{l}\text { S. } \\
\text { mutans }\end{array}$ \\
\hline DMSO & - & - \\
\hline Amoxicillin & $\begin{array}{l}11,1 \\
\mathrm{~mm}\end{array}$ & $\begin{array}{l}10,5 \\
\mathrm{~mm}\end{array}$ \\
\hline $\begin{array}{l}\text { Ekstrak } \\
\text { konsentrasi } \\
\text { 300 mg/ml }\end{array}$ & $7,1 \mathrm{~mm}$ & $4,5 \mathrm{~mm}$ \\
\hline $\begin{array}{l}\text { Ekstrak } \\
\text { konsentrasi } \\
400 \text { mg/ml }\end{array}$ & $7,9 \mathrm{~mm}$ & $5,4 \mathrm{~mm}$ \\
\hline $\begin{array}{l}\text { Ekstrak } \\
\text { konsentrasi } \\
500 \text { mg/ml }\end{array}$ & $9,7 \mathrm{~mm}$ & $6,7 \mathrm{~mm}$ \\
\hline
\end{tabular}

Berdasarkan hasil pengukuran yang terdapat pada Tabel 3 dapat terlihat diameter zona hambat terbesar ada pada kelompok amoxicillin sebagai kontrol positif yaitu sebesar $11,1 \mathrm{~mm}$ pada bakteri Staphylococcus aureus dan 10,5 $\mathrm{mm}$ pada bakteri Streptococcus mutans, sedangkan ukuran diameter zona hambat yang paling besar terdapat pada kelompok ekstrak daun melinjo (Gnetum gnemon L.) yaitu dengan konsentrasi $500 \mathrm{mg} / \mathrm{ml}$ sebesar 9,7 $\mathrm{mm}$ pada bakteri Staphylococcus aureus dan $6,7 \mathrm{~mm}$ pada bakteri Streptococcus mutans dan memiliki diameter zona hambat yang paling kecil pada konsentrasi $300 \mathrm{mg} / \mathrm{ml}$ yaitu sebesar 7,1 $\mathrm{mm}$ pada bakteri Staphylococcus aureus dan 4,5 mm pada bakteri Streptococcus mutans. Pada pengukuran kontrol negatif menggunakan DMSO, tidak ada terbentuk zona hambat. Efek antibakteri yang terdapat pada daun melinjo dikarenakan daun melinjo mengandung senyawasenyawa kimia. Kining (2015) melakukan uji fitokimia terhadap daun melinjo, dari penelitiannya diketahui bahwa senyawa yang bersifat sebagai antibakteri pada daun melinjo adalah saponin, alkaloid, steroid, dan tannin. Saponin memiliki sifat lyobipolar artinya senyawa ini memiliki kemampuan untuk berinteraksi dengan membran sel. Berdasarkan penelitian yang dilakukan oleh Thakur pada tahun 2011, tumbuhtumbuhan banyak menghasilkan saponin. Menurut penelitian Cheeke (2004), saponin bekerja dengan cara merusak stabilitas pada membran sel bakteri sehingga menyebabkan terjadi lisis pada sel bakteri.

\section{KESIMPULAN}

Setelah didapatkan hasil pada penelitian ini dapat disimpulkan ekstrak daun melinjo (Gnetum gnemon L.) memiliki kemampuan sebagai antibakteri yang bermanfaat dalam menghambat 
pertumbuhan

Staphylococcus

Streptococcus mutans dengan besar diameter zona hambat $9,7 \mathrm{~mm}$ dan $6,7 \mathrm{~mm}$ pada ekstrak konsentrasi $500 \mathrm{mg} / \mathrm{ml}$. Pernyataan ini membuktikan bahwa ekstrak etanol daun melinjo memiliki efek antbakteri.

Penelitian lanjutan yang disrankan yaitu tentang uji aktivitas daun melinjo dengan konsentrasi, metode yang berbeda dan bakteri yang berbeda juga dan perlu juga untuk dilakukan penelitian lanjutan tentang Kadar Hambat Minimum (KHM) dari ekstrak daun melinjo (Gnetum gnemon L.).

\section{DAFTAR PUSTAKA}

Cheeke, R.P. (2004). Saponins: surprising benefits of desert plants. USA: Linus Pailing Institute.

Cowan, M. (1999). Plant products as antimicrobial agents. Clin Microbio Reviews. 12(4): 56482.

Hariana, H.A. (2008). Tumbuhan Obat dan Khasiatnya Seri 2. Jakarta. Penebar Swadaya. 117-18.

Jawetz, dkk. (2008). Microbiology Untuk Profesi Kesehatan Edisi 16. Jakarta: EGC. Hal: 239244
Kining, E. (2015). Aktivitas Antibiotic Ekstraks Air Daun Melinjo, Daun Singkong, dan Daun Papaya Terhadap Bakteri Pseudomas Aeruginosa Secara In Vitro. Bogor. Hal: 9-25

Natalia, dkk. (2016). Uji Daya Hambat ekstrak Daun Melinjo (Gnetum gnemon L.) Terhadap Pertumbuhan bakteri Streptococcus mutans. Fakultas Kedokteran UNSRAT: Manado. ISSN 2302-2493.

Noor, M.A., Apriasari, M.L. (2014). Efektivitas Antibakteri Ekstrak Methanol Batang Pisang Mauli (Musa Acumuminata) dan Povidone Iodine $10 \%$ Terhadap Streptococcus Mutans. Jurnal PDGI. Vol. 63(30). Hal 78-8

Rafika S., dkk. (2017). Uji Aktivitas Antibakteri Ekstrak etanol Daun Gaharu (Aquilaria microcarpa Baill.) Terhadap Bakteri Staphylococcus aureus dan Proteus mirabilis.

Stevani. (2016). Kajian Etnobotani Tumbuhan Obat di Desa Cicangkang Bandung Barat. Skripsi FKIP, UNPAS.

Thakur, M., Melzig, M.F., Fuchs, H., Weng, A. (2011). Chemistry and pharmacology of saponins: special focus on cytotoxic properties. 19-29. 